\title{
Talking about succession in stricto sensu post-graduate programs in Accounting
}

\author{
Jacqueline Veneroso Alves da Cunha ${ }^{1}$ \\ (D) https://orcid.org/0000-0003-2522-3035 \\ Email: jvac@face.ufmg.br
}

${ }^{1}$ Universidade Federal de Minas Gerais, Faculdade de Ciências Econômicas, Departamento de Ciências Contábeis, Belo Horizonte, MG, Brazil

Correspondence address

Jacqueline Veneroso Alves da Cunha

Universidade Federal de Minas Gerais, Faculdade de Ciências Econômicas, Departamento de Ciências Contábeis

Avenida Presidente Antônio Carlos, 6627 - CEP 31270-901

Pampulha - Belo Horizonte - Minas Gerais - Brazil

\section{INTRODUCTION}

The issue of succession is an important topic and is a core concern of companies, especially in those characterized as family businesses. In this type of entity, questions related to the liquidity of existence, addressed by Bauman (2007a, 2007b, 2008), and to the founder's dream (Flores \& Grisci, 2012) are more present, primarily due to the affective/emotional/professional involvement of the players in the process.

Problems of succession are also pressing in nonfamily businesses. They are more dramatic in those with no successors ready to assume command (Charan, 2005) and in state enterprises, in which they are also related to political and electoral processes (Guimarães $\&$ Silva, 2020). A successful succession process can be key to the endurance and perpetuation of an entity; that is, it is only through the process of succession that a business can expect to endure in the long run (Flores \& Grisci, 2012).

Within the area of universities and, more specifically, in post-graduate programs, the reality is no different. Discussing succession in stricto sensu post-graduate programs in accounting obligatorily involves the same dilemmas concerned in any other organizational environment.

After more than 50 years since the creation of the first master's course in accounting by the School of Economics, Business, and Accounting of the University of São Paulo (FEA-USP), and at a time when the area has more than 30 other programs, including academic and professional master's and doctoral courses, succession in both the administrative and academic areas still remains to be included on the agenda for discussion, despite this already being a reality in some institutions.

\section{STRICTO SENSU POST-GRADUATE PROGRAMS IN ACCOUNTING}

The characteristics of stricto sensu post-graduate programs in accounting are quite peculiar. They are relatively new, having been around for less than 20 years. In most of them, the people who developed the project to create the program and who were responsible for implementing it are still present and active and, to a certain extent, continue to drive it forward.

In each one of the currently existing programs there is still at least one professor from the first program at FEA-USP, who maintains an open dialogue and a bridge 
between them, conserving the important balance between the old and new.

We have yet to undergo a full succession process in the post-graduate programs; in some cases, we have witnessed a few retirements and substitutions, but where the departures appear to be merely formal. The pioneers have continued to be present and active, orbiting the programs and performing their roles with the proprietorship that experience has given them, accompanying the performance of substitutes and seeking to prevent any break from the status quo.

Thus, it is imperative for us to include on the agenda a discussion of the succession process in the stricto sensu post-graduate programs in accounting and in their representative entities, both in terms of succession in the occupation of administrative roles and in the occupation of the academic positions. Aspects related to choices of new course coordinators, heads of department, and unit directors lie within the administrative sphere. Within the academic sphere, succession is directly related to the continuity of research, course structures, the outlining of policies, and the leadership of representative entities, such as the National Council for Scientific and Technological Development (CNPq), the Coordination for the Improvement of Higher Education Personnel (Capes), the National Association of Post-Graduate Programs in Accounting (Anpcont), and journal editorial teams, among others.

Some questions are important when discussing succession in post-graduate programs. Who makes up the group responsible for continuing the work begun by distinguished professors? Have we been concerned about this? When we teach courses and advise our students, are we really aware that those master's and $\mathrm{PhD}$ students could be our successors? Have we paid attention to building values in those responsible for substituting us and spreading our ideas and ideals? Have we been an example of good behavior? And, especially, have we shown how to continue the process of growing the area in which we work? The answer to some of these questions is likely to be no. It is not part of human nature to face the succession process, even though this is an ever approaching reality.

\section{THE PREDECESSOR AND THE SUCCESSOR}

The succession process is based on the conception of Scheffer (1995): a rite of power transfer between the generation currently in charge and the one that will be in charge tomorrow. There are various situations and conflicts involved in an imminent succession, whether it is planned or not: questions related to the complexity involved in the scenario and in the personal relationships, giving up leadership, new management models, generational differences, perspectives, expectations, thinking, ideas, and the completely different actions of the players.

This process raises dilemmas related to finiteness, the life-death duality, and the search for legitimacy, which can influence and even be determinants for the treatment and the development of the succession environment, causing positive and negative consequences.

When we look at our own trajectory in postgraduation, it is easy to perceive that some "posts" have been successively occupied by the same individuals. There is almost no variation in the occupation of roles. It is true that there are still not many of us, but it is clear that, with so much to do, we have not invested time in training successors. We teach courses, advise, develop research projects, but we never think about our own succession.

It is worth highlighting that a lack of people interested in assuming the baton and getting involved in the "business" is not the only scenario that occurs. There exists an antagonistic situation, in which there are various proponents interested in participating in our succession process, in choosing a successor, giving rise to the figure of one or various non-successors. This can come to generate conflicts of another nature: conflicting proposals.

\subsection{The Successor's Challenge}

The successor can face conflicts in their search for an identity, cutting off ties with the predecessor, as they are eager to assume their position and be recognized for their brilliant actions. They could easily seek the participation of the predecessor to support their initiative and growth, not as a model to be followed, but as a way of respecting past and fruitful actions.

For the successor, besides the discomfort of assuming the new position, there is the conflict of power and the search for legitimacy, especially considering that, in many cases, those predecessors were the teachers, mentors, tutors, and advisers of the successors. In this case, the roles can be confused, generating new conflicts.

If the predecessor was centralizing and authoritarian, they can present difficulties in detaching themselves from the roles and prevent the growth and development of their successors. By acting in an overprotective and restrictive way, they may leave no space for the transmission of 
positive values. This can certainly generate social mistrust, in situations in which the interested parties and peers express a feeling of rejection by the successor. However, it is necessary to remember that, for the successor to be successful, certain conditions need to be fulfilled, such as acceptability, credibility, legitimacy, and leadership.

Thus, the succession process involves not only the transfer of physical and human capital, but also social capital; it covers the social ties, trust relationships, and values systems of the individuals immersed in the context (De Freyman \& Richomme-Huet, 2010; De Freyman et al., 2006).

\subsection{The Dilemma of the Predecessor}

For Bauman (2008), a major dilemma experienced by humanity is so-called liquid modernity, which is the fear of being excluded, being disposable, becoming worthless, and, consequently, accepting one's own finiteness. In this sense, the transition of power can give rise to ambiguous feelings. On one hand, the successor may be seen by the predecessor as a threat. Even with a clear understanding that succession is the only path, the predecessors can experience a form of metaphoric grief (Bauman, 2008; Sonnenfeld, 1988). The literature indicates that giving up leadership is more difficult than is imagined (Lansberg, 1999; Poza, 2004; Sonnenfeld, 1988; Tondo 2008). Few are ready to surrender it.

The positive side is that the predecessor can experience a feeling of duty fulfilled and see their successor as the person responsible for continuing the process, making both their academic and administrative experience and maturity available for the growth and improvement of the program. Starting something is always very complicated, changing something is always very complicated, and accepting changes is always very complicated.

It is essential to be able to leave the main stage without giving up one's role and one's trajectory. The history of the pioneers, as figures who are respected by the whole community, is intertwined with that of the post-graduate programs, forming part of the poetic imagination.

Overcoming the ambivalence that affects those predecessors and their successors in the execution of their combined work helps to perpetuate the interests of post-graduate programs. Giving up leadership, but not ceasing to accompany and participate along with the successor, is a blessing and a need. Full awareness of and the ability to appreciate one's own achievements are incentives for the transfer of power.

\section{FINALLY...}

Despite the whole ambiguity of feelings involved in the succession process, it needs to be clearly understood that the program goes beyond one life cycle. It is necessary to find space to assume new future visions without placing its survival at risk.

The ideal way would be to think of succession not only as an event, but above all as a process; establishing a plan, a standard for its accomplishment. If until now we have not thought about training people to occupy our places, or we have only been concerned about training researchers and professionals, we urgently need to prepare for when we give up our leadership, to face our finiteness, and to worry about the maintenance of the programs.

Sooner or later we all experience a succession process, involving considerable complexity and attribution, meaning that it is imperative to minimize the negative impact that this can cause on the programs and on their management. For this, we need to have attitudes such as acceptance of finiteness, separation between emotions and reason, and appreciation of seniority (but not as an attribute that outweighs competence), understanding that the succession process is a major challenge, inevitable, and normally neglected, but not necessarily traumatic. There is the possibility of the predecessor continuing to participate as a support agent but remaining distant enough for the successor's projects to flourish. In particular, it needs to be clearly understood that the professional ascension of the successor does not necessarily imply the downfall of the predecessor.

This process involves overcoming the confusion between management and ownership, identifying potential successors in post-graduate students, and working towards this. In particular, it needs to be understood that personal academic objectives can be fully achieved, ensuring the long-term success of the program, and that the succession process has positive and negative consequences, including for the organizational culture and for the reputation of the program. After all, conflicts form part of all relationships and contribute to their development. 


\section{REFERENCES}

Bauman, Z. (2007a). Tempos líquidos. Jorge Zahar.

Bauman, Z. (2007b). Vida líquida. Jorge Zahar.

Bauman, Z. (2008). Medo líquido. Jorge Zahar.

Charan, R. (2005). Ending the CEO succession crisis. Harvard Business Review, 83(2), 72-81. https://doi. org/10.2307/1336931

De Freyman, J., \& Richomme-Huet, K. (2010). Entreprises familiales et phénomène successoral: pour une approche intégrée des modes de transmission. Revue Française de Gestion, 36(200), 161-179. https://doi.org/10.3166/ rfg.200.161-179

De Freyman, J., Richomme-Huet, K. \& Paturel, R. (2006). Condition model for transferring social capital in family business succession. In Proceedings of the 3rd International Research Entrepreneurship Exchange (161-179).

Flores Jr., J. E. \& Grisci, C. L. I. (2012). Dilemas de pais e filhos no processo sucessório de empresas familiares. Revista de Administração (São Paulo), 47(2), 325-337. https://doi. org/10.1590/S0080-21072012000200012

Guimarães, S. F., \& da Silva, A. L. C. (2020). Eleições e sucessão de CEOs em empresas estatais brasileiras. Revista Brasileira de Gestão de Negócios, 22(special edition), 462-481. https://doi. org/10.7819/rbgn.v22i0.4060

Lansberg, I. (1999). Succeeding generations: realizing the dream of families in business. Harvard Business School Press.

Poza, E. J. (2004). Family business. Thomson South-Western.

Scheffer, A. B. B. (1995). Fatores dificultantes e facilitadores ao processo de sucessão familiar. Revista de Administração (São Paulo), 30(3), 80-90.

Sonnenfeld, J. (1988). The hero's farewell: what happens when CEOs retire. Oxford University Press.

Tondo, C. (Org.). (2008). Desenvolvendo a empresa familiar e a família empresária. Sulina. 